\title{
Agroparks as a network form of business organization in agriculture
}

\author{
Andrey Plakhin*, Tatiana Kochergina, and Maria Selezneva \\ Ural State University of Economics, 8 Marta Str, 62, 620144 Ekaterinburg, Russia
}

\begin{abstract}
In this study, the authors substantiate the relevance of the creation of agro-industrial parks as a network form of organizing the business of agricultural producers. Agro-industrial parks in modern conditions are becoming a kind of growth points for the innovative development of agricultural producers, providing accelerated growth in production and import substitution in order to achieve food security in the Russian Federation and its regions. The results of the study allow us to conclude about the growing interest in this form of business organization.
\end{abstract}

\section{Introduction}

The tasks associated with the intensification of the development of both individual constituent entities and the Russian Federation as a whole require more and more innovative conjugation of participants in the process of production and processing of agricultural products in the interests of import substitution and ensuring food security. Based on the theoretical provisions of the development of organizational forms of business integration, the concept of uniting the participants in the process of production and processing of agricultural products through the formation of agro-industrial park structures was formed $[1,2,3]$.

The arguments in favor of this thesis are the following main opportunities provided by agro-industrial parks:

- coordinating the actions of participants in the agro-industrial sector, creating conditions for cooperation, inter-firm networking, clustering and building an effective chain of consumer value formation, obtaining business advice and data on the conjuncture of sales markets;

- provision of financial incentives and tax preferences - reduction of tax rates, exemption (temporary) from certain types of taxes;

- provision of the necessary engineering, transport, production, sales and logistics infrastructure;

- development of new technologies and new products with improved consumer properties, etc.

Agricultural parks perform an important function of uniting entrepreneurs working in different sectors of the agri-food market into production and distribution structures. Such structures allow uniting agricultural producers and processing enterprises, implementing the provisions of the network theory and forming a number of relational effects for the

\footnotetext{
*Corresponding author: apla@usue.ru
} 
participants [4]. At the same time, agro-industrial parks expand the innovative component of entrepreneurial activity by stimulating the exchange of innovations both between residents of the agro-park and among other participants in production and distribution networks [5].

\section{Materials and Methods}

Based on the provisions of the network theory, it can be assumed that the use of resources, including land within the framework of agro-industrial structures is more efficient in comparison with the competitive form of interaction between agricultural producers. The resource component of the agricultural park, as a rule, includes significant land, road and engineering infrastructure for the comprehensive provision of industrial enterprises that process agricultural products. Also, a number of authors emphasize the need to provide services to residents in research, marketing, legal and other areas [6,7].

Analysis of the experience of the formation of agro-industrial parks allows us to identify three main models used in Russia. Figure 1 shows a model of an agricultural park operating on the basis of public-private partnerships.

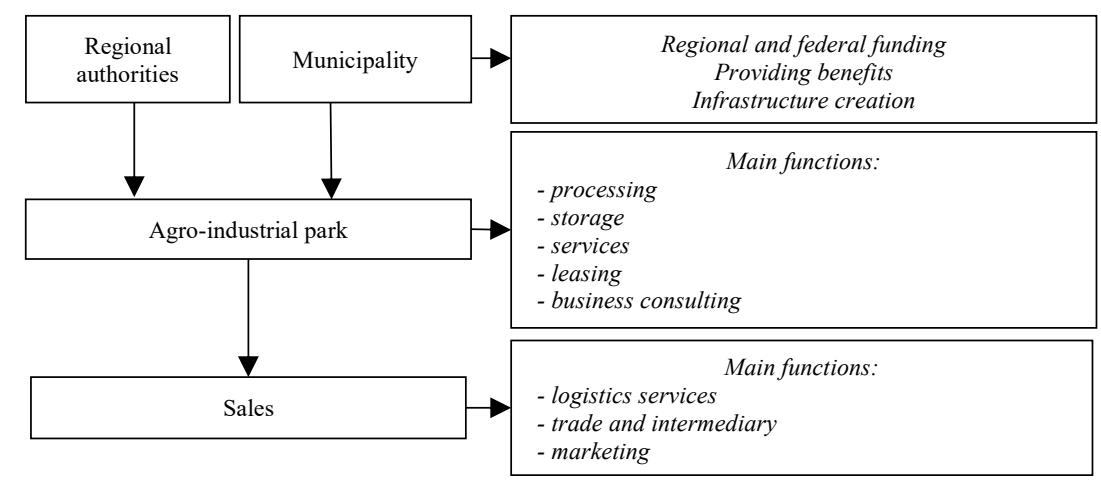

Fig. 1. Model of an Agropark, created on the basis of public-private partnership

In modern practice, the most often used model is the formation of an agro-industrial park, created on the basis of a public-private partnership, by the initiators of projects of this kind is based on the initiative of state and municipal authorities.

The second model of the emergence of agro-industrial parks is based on a complex of processing industries that form an agricultural holding with a different ownership structure, Figure 2 .

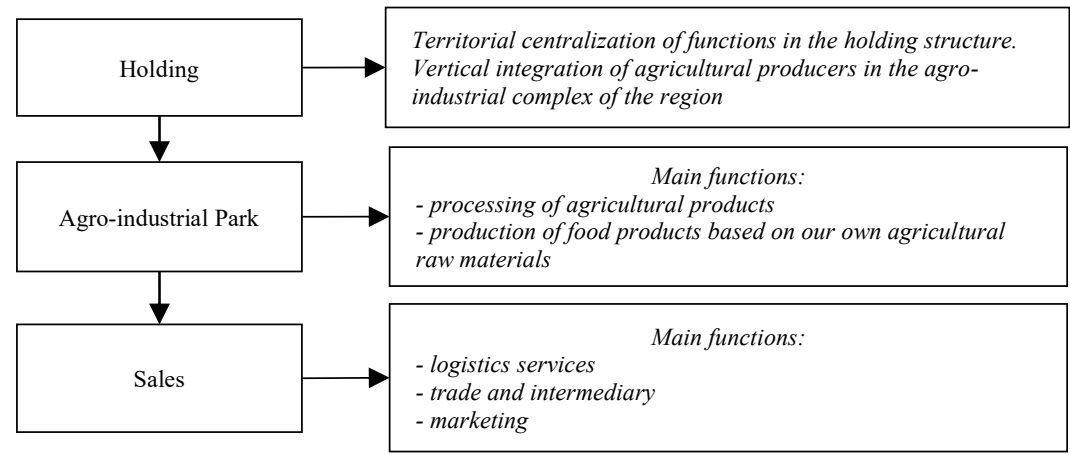

Fig. 2. Model for creating an agricultural park on the basis of an agricultural holding 
As a rule, agro-industrial parks of this type are formed in traditional agricultural regions of Russia. The most rare is the model of the formation of agro-industrial parks based on the creation of organizations providing complexes of service functions to agricultural producers, Figure 3.

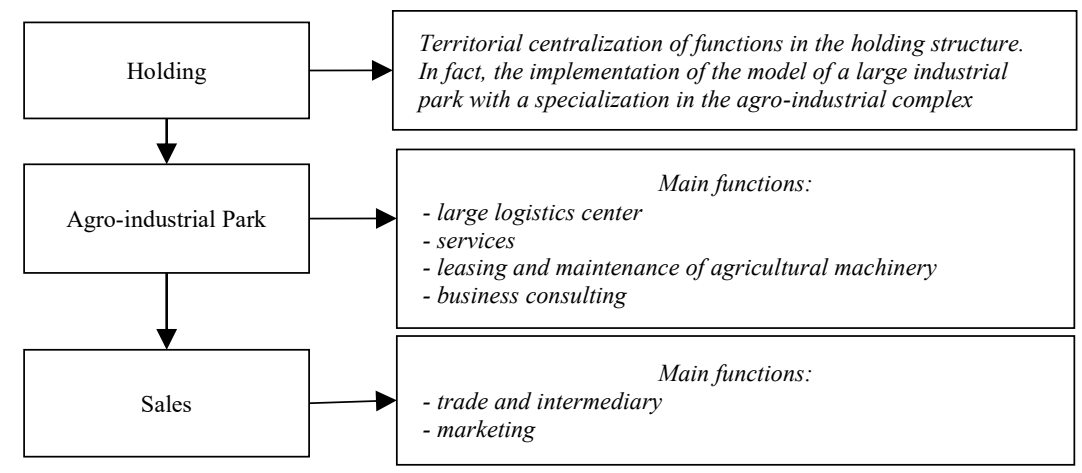

Fig. 3. Model for creating an agricultural park based on a service holding

All the presented models of aroparks make it possible to create regional centers that combine functions within the production and distribution network, which makes it possible to form and use a wide range of additional effects based both on the scale of production and on the effect of specialization.

\section{Results and Discussion}

Let's present the data on the formed base of agricultural parks in the Russian Federation. Figure 4 shows the data on the distribution of agricultural parks by form of ownership

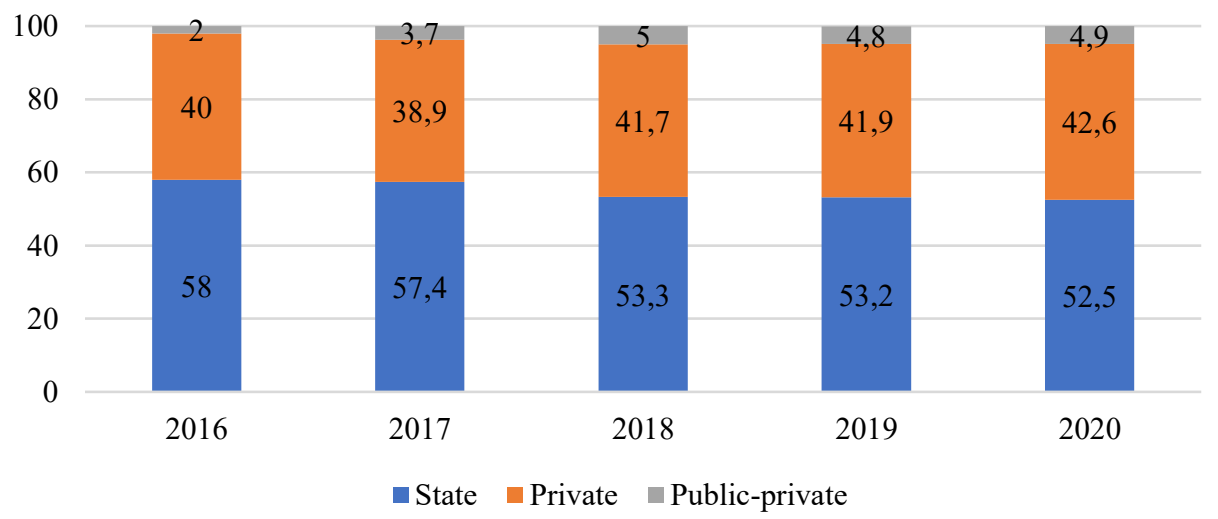

Fig. 4. Data on the distribution of agro-industrial parks by ownership, 2016-2020, \%

As one can see in the figure, the share of state agricultural parks is gradually decreasing, giving way to projects initiated by commercial structures and within the framework of publicprivate partnership projects. Next, we will characterize the structure of agricultural parks by the stage of project implementation, Figure 5. 


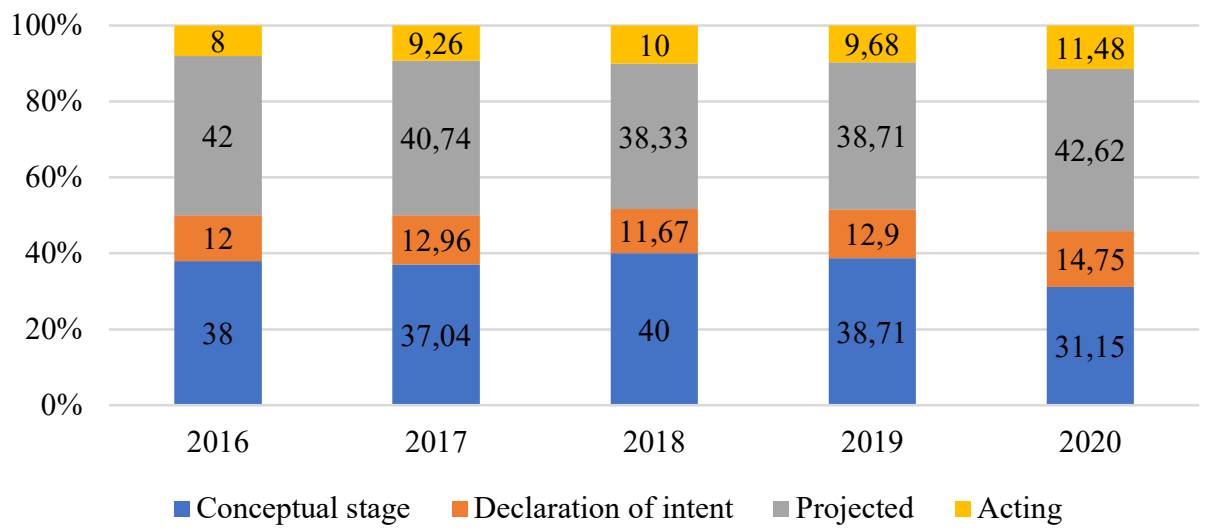

Fig. 5. Data on the distribution of agro-industrial parks by the stage of project implementation, 2016$2020, \%$

As one can see in the figure, most agricultural parks are at the design and construction stage, this circumstance indicates the demand for this format of doing business. As a rule, the agro-park format is most actively used in resource-abundant regions specializing in the production of agricultural raw materials. Interesting is the information on the distribution of agricultural parks by area of land resources included in the turnover, Figure 6.

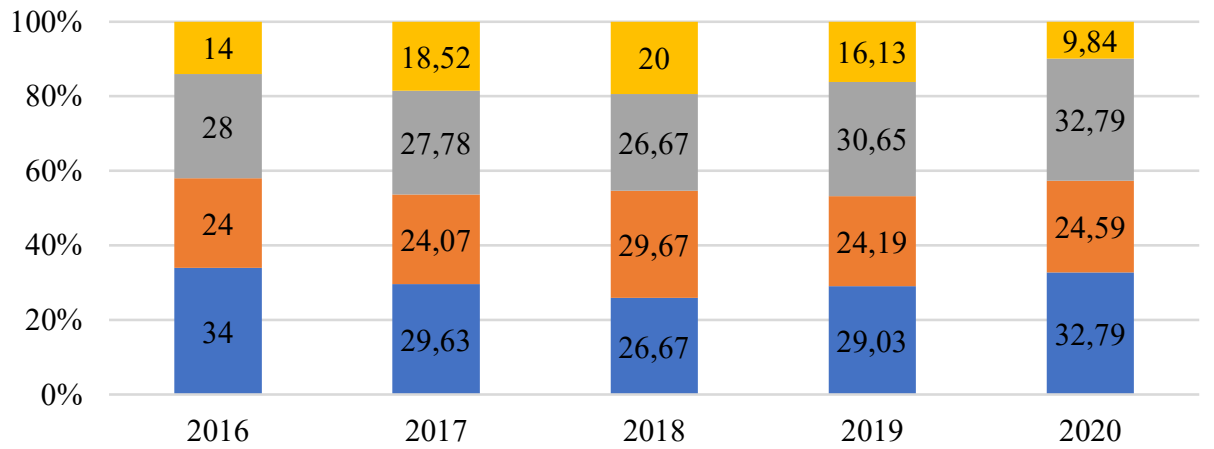

$\square$ up to 100 hectares $\square 100$-200 hectares $\square 200$ - 1000 hectares $\square$ more than 1000 hectares

Fig. 6. Data on the distribution of agro-industrial parks by area of land plots, 2016-2020, \%

As can be seen in the figure, there is almost complete parity in the area of land plots included in the agricultural park. It can be concluded that projects are equally attractive for investors with relatively small areas of up to 100 hectares and with large areas included in the agricultural park.

\section{Conclusion}

At present, agro-industrial parks built on the principles of clustering are showing increasing efficiency. The point is that in the process of creating an agro-industrial park, the possibilities of concentrating technologically related enterprises on its territory are being investigated. 
In a narrow sense, a cluster is understood as "the geographical concentration of enterprises that benefit from their joint location on the same territory" [8]. In a broader sense, a cluster is "a collection of geographically concentrated interconnected enterprises and organizations in a specific area or industry." Clusters can be a collection of interconnected manufacturing enterprises and specific organizations that result in a higher level of competitiveness. Such organizations include, for example, suppliers of specialized materials such as components, mechanisms and services, as well as companies that form specific infrastructure.

Clusters are also characterized by vertical expansion "down" in relation to distribution channels and consumers of products and horizontal expansion towards both producers of additional components and companies in industries related to education, science, technology or other general needs. It should be noted that in the leading industrialized countries, clusters actively interact with government agencies, universities, standards setting and development agencies, think tanks, vocational education organizations, trade associations, which together provide specialized training, education, information, research, and technical support, which is very important for the agricultural sector and the agricultural parks created here.

\section{References}

1. I. Doronina, V. Borobov, E. Ivanova, E. Gorynya, B. Zhukov, International journal of economics and financial issues, 6, 1 (2016)

2. A. Sharnin, O. Frolova, G. Klychova, N. Nigmatullina, A. Iskhakov, Formation and development of clusters in the Russian regional agro-industrial complex In E3S Web of Conferences, 91 (2019)

3. D. V. Zavyalov, O. V. Saginova, N. B. Zavyalova, Journal of Environmental Management \& Tourism, 8 (2017)

4. A. Plakhin, I. Semenets, E. Ogorodnikova, The asymmetry of income distribution between stakeholders within the framework of industrial park structures In MATEC Web of Conferences, 184 (2018)

5. A. Plakhin, E. Ogorodnikova, M. Khokholush, T. Guseva, M.Selezneva, Revista Inclusiones, 7 (2020)

6. A. Semin, A. Truba, The economics of agriculture in Russia, 7 (2019)

7. R. Akhmadeev, A. Redkin, N. Glubokova, Entrepreneurship and sustainability issues, 7 (2019)

8. M.Graubner, I. Ostapchuk, T. Gagalyuk, European Review of Agricultural Economics, 48, 1 (2021) 